\title{
Examinations of Polish brown and hard coals in terms of their use in the steam gasification process
}

\section{Introduction}

In recent years, the dynamic development of the coal gasification technology has been observed worldwide, including Poland (Higman 2014; Strugała and Czerski 2012). Currently, a number of commercial gasification technologies are available, making use of reactors with a fixed, fluidized or entrained bed (Dreszer and Wiecław-Solny 2007). Additionally, technologies are being developed which utilize a burner based on a rocket jet (Draby 2014), or a plasma reactor (Howard 2013). However, particular technologies have, , their limitations concerning the application of specific kinds of coal (Dreszer and Wiecław-Solny 2007). Entrained bed reactors and fixed bed wet bottom reactors with (slugging gasifiers) are suitable for the gasification of practically every kind of coal, due to a very high temperature prevailing in them. By contrast, the fluidized bed reactors, entrained bed reactors and fixed bed dry bottom reactors require highly reactive coals (Collot 2006), on account of applying relatively low gasification temperatures, i.e. below the ash melting point. Moreover, brown coals cannot be used in the case of entrained bed reactors with coal dosing in the form of water suspension,.

\footnotetext{
* Professor AGH, **PhD, Eng., *** MSc. Eng., AGH University of Science and Technology, Faculty of Energy and Fuels, Krakow; e-mail: porada@agh.edu.pl
} 
The basic criterion for evaluating the suitability of coals for gasification is their reactivity. There is a number of ways of determining this, namely: the comparison of the shape of the carbon conversion degree curves (Coetzee et al. 2013; Everson et al. 2006; Murakami et al. 2015; Peng et al. 1995; Sharma et al. 2008; Wang et al. 2009, 2010; Ye et al. 1998), the determination of the time of partial carbon conversion $\tau_{0.5}$ (Smoliński 2011; Wu et al. 2003), the determination of the reactivity index $R_{x}$ (Wang et al. 2010; Wu et al. 2003; Ye et al. 1998), the determination of the reaction rate constant $k$ for carbon conversion ( $\mathrm{Li}$ and Li 2006; Molina and Mandragon 1998; Yasushi et al. 2006), or the comparison of the net conversion of the primary char (Zhang et al. 2013). An assessment of the reactivity of coals can also be conducted based on a comparison of the course of formation of gaseous products of gasification (Matsuoka et al. 2009; Porada et al. 2014a). Moreover, the content of ballast components, i.e. moisture and ash as well as the content of undesirable components, including sulfur, chlorine or mercury, constitute very important parameters characterizing the suitability of coals for gasification. The melting temperature of ash is also highly significant for all types of gasifiers, and, in the case of entrained bed gasifiers, additionally, the molten ash viscosity. In the case of the necessity to crush and mill coal before gasification, coal grindibility plays an important part, which, apart from technological significance, is also an important economic factor translating into operating costs (Porada et al. 2014b). In addition, the utilization of solid wastes from coal gasification is also an important issue (Mazurkiewicz et al. 2012, 2013).

In the work, the suitability of selected Polish coals for gasification was assessed. The examinations were conducted with the use of an experimental equipment, which allows for the examinations of steam gasification of solid fuels within a broad pressure range. The following parameters were determined for the examined coals: reactivity, maximal carbon conversion degree, amount and composition of the resulting gas as well as the reaction rate constants of the formation of particular gas components. Moreover, coal ash fusibility, and the content of selected impurities, i.e. sulfur, chlorine and mercury, were determined for the analyzed coals.

\section{Materials and method}

\subsection{Examined coals}

For the purposes of the investigations, eight Polish coals, used by domestic coal-fired power plants, were selected. The examined coals were derived from five hard coal mines: Bogdanka, Janina, Piast, Sobieski and Wieczorek, as well as from three brown coal seams: Bełchatów, Sieniawa and Turów. For the analyzed coals, proximate and ultimate analyses were conducted and the composition of ash was determined. The results of the analyses are shown in Table 1. 
Table 1. Characteristics of examined coals

Tabela 1. Charakterystyka badanych węgli

\begin{tabular}{|l|r|r|r|r|r|r|r|r|r|}
\hline \multirow{2}{*}{ Paremeter } & \multicolumn{7}{c|}{ Hard coal } & \multicolumn{4}{c|}{ Brown coal } \\
\cline { 2 - 10 } & Bogdanka & Janina & Piast & Sobieski & Wieczorek & Bełchatów & Sieniawa & Turów \\
\hline \multicolumn{7}{|c|}{ Proximate analysis [\%] } \\
\hline Moisture $-\mathrm{M}^{\mathrm{a}}$ & 3.4 & 10.6 & 4.1 & 11.1 & 3.6 & 10.4 & 19.9 & 8.5 \\
\hline Ash $-\mathrm{A}^{\mathrm{a}}$ & 5.7 & 6.0 & 5.8 & 7.3 & 2.7 & 21.3 & 9.6 & 9.9 \\
\hline Volatile matter $-\mathrm{VM}^{\text {daf }}$ & 38.5 & 35.9 & 39.9 & 38.8 & 33.3 & 58.0 & 55.4 & 57.5 \\
\hline \multicolumn{7}{|c|}{ Ultimate analysis [\%] } \\
\hline $\mathrm{C}^{\text {daf }}$ & 82.2 & 80.0 & 81.2 & 84.1 & 85.5 & 67.5 & 72.5 & 70.8 \\
\hline $\mathrm{H}^{\text {daf }}$ & 5.4 & 4.8 & 5.2 & 4.9 & 4.8 & 5.9 & 4.9 & 6.1 \\
\hline $\mathrm{S}_{\mathrm{t}}^{\mathrm{d}}$ & 1.38 & 1.62 & 0.88 & 1.07 & 0.35 & 0.81 & 1.88 & 1.1 \\
\hline
\end{tabular}

\subsection{Equipment and methodology of examinations}

Examinations of the gasification process were conducted with the use of the laboratory equipment presented in Figure 1, which makes it possible to subject both coals and chars with different grain size distribution at a high pressure to the process of gasification. The equipment and the applied methodology have already been thoroughly described (Porada and Rozwadowski 2014; Porada et al. 2015). The equipment consists of three basic systems: a pressure reactor with a heating system, a system for supplying the reactor with steam, an inert gas (argon) and coal as well as a system for collecting and analyzing the resulting gas. The content of carbon monoxide and carbon dioxide in the resulting gas is continuously determined with an analyzer utilizing the principle of the infrared radiation absorption. Moreover, gas samples are taken, in order to be analyzed later in respect of the content of hydrogen and gaseous hydrocarbons. To that end, two gas chromatographs are used. One of them, equipped with a flame ionization detector (FID), serves for analyzing hydrocarbons, and the other one with a thermal conductivity detector (TCD) is used for determining the content of hydrogen.

The process of gasification was examined for the pressure of $1.5 \mathrm{MPa}$, at the temperature of $900^{\circ} \mathrm{C}$. Steam was dispensed in an amount equal to $0.3 \mathrm{~g} / \mathrm{min}$. Based on the measurements of concentrations of carbon monoxide, carbon dioxide and methane in the resulting gas, with the use of the equation (1), changes in the carbon conversion degree in time were calculated. Based on the formulae (2-5), the time of partial conversion $\tau_{0.5}$ and reactivity index $R_{0.5}$ as well as the reaction rate constant of carbon conversion were determined. 


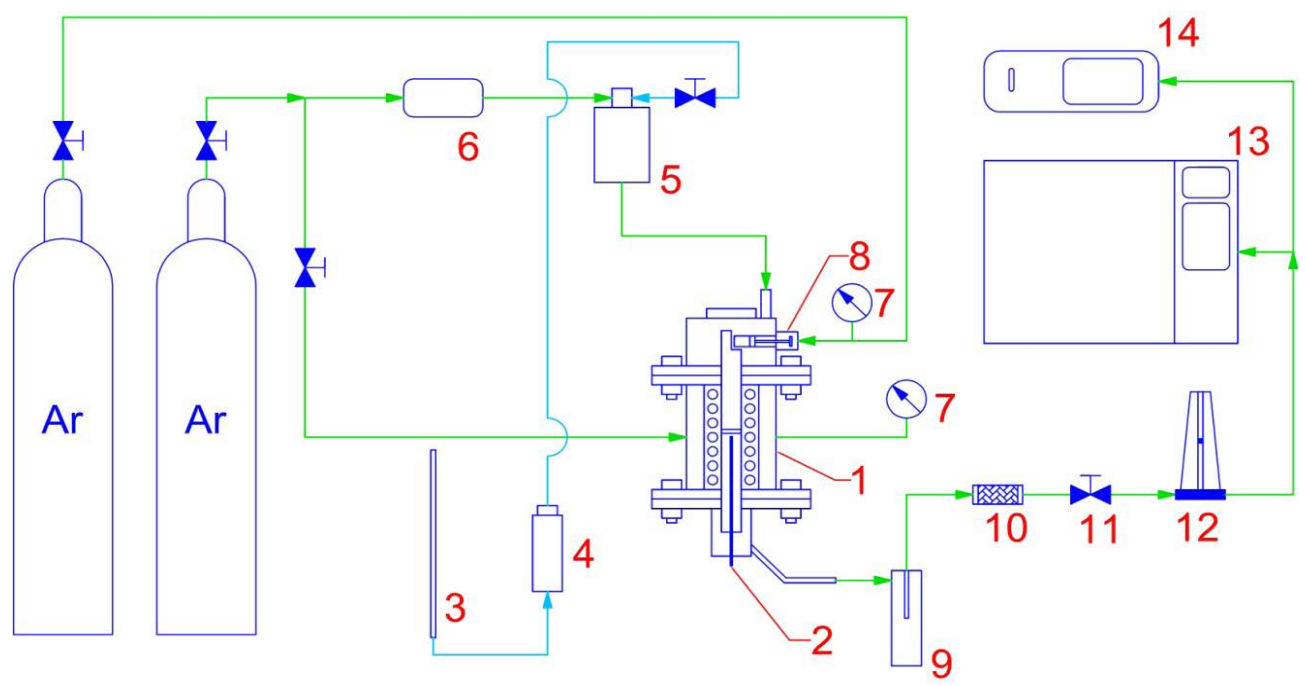

Fig. 1. Schematic diagram of reactor system used to analyze steam coal gasification process 1 - reactor, 2 - thermocouple, 3 - water tank, 4 - water pump, 5 - steam generator, 6 - mass flowmeter, 7 - pressure gauge, 8 - coal feeder, 9 - cooler, 10 - filter, 11 - pressure regulator, 12 - rotameter, 13 - gas chromatographs, $14-\mathrm{CO}, \mathrm{CO}_{2}$ IR analyzer

Rys. 1. Schemat stanowiska pomiarowego procesu zgazowania węgli parą wodną 1 - reaktor, 2 - termopara, 3 - pipeta $\mathrm{z}$ wodą, 4 - pompa wody, 5 - wytwornica pary, 6 - regulator przepływu argonu, 7 - manometr, 8 - podajnik węgla, 9 - chłodnica, 10 - filtr,

11 - reduktor, 12 - rotametr, 13 - chromatografy gazowe, 14 - analizator $\mathrm{CO}, \mathrm{CO}_{2}$

The kinetics of gaseous products formation during steam gasification was also analyzed. On the basis of Eq. (6), the rate constants of formation of carbon monoxide, carbon dioxide and hydrogen were calculated.

Coal ash fusibility was determined using the CAF Digital analyzer produced by Carbolite. The mercury content was measured by means of the MA-2000 mercury analyzer manufactured by Japanese company Nippon Instruments Corporation. The apparatus utilizes the method of Cold Vapor-Atomic Absorption Spectrophotometry (CVAAS).

\subsection{Methodology of reactivity evaluation}

An evaluation of the reactivity of the examined coals was made in a number of ways. First, the shape of the curves of carbon conversion degree, calculated in accordance with the equation (1), was compared:

$$
X=\frac{\left(V_{C O}+V_{C O_{2}}+V_{C H_{4}}\right) \cdot M_{C}}{V_{m o l} \cdot m \cdot C^{d a f}} \cdot 100 \%
$$




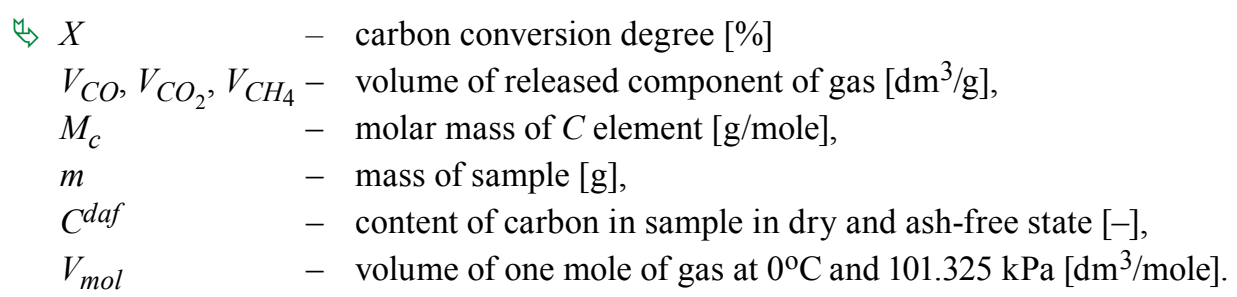

On the basis of the carbon conversion curves, the time of partial conversion $\tau_{0.5}$ was determined, defined as the time after which $50 \%$ of the $C$-element underwent gasification, as well as the reactivity index $R_{0.5}$ defined by the Equation (2):

$$
R_{x}=\frac{0.5}{\tau_{0.5}}
$$

$\stackrel{M}{\rightarrow} R_{0.5}-$ reactivity after reaching $50 \%$ of the conversion degree of the $C$ element $\left[\mathrm{min}^{-1}\right]$,

$\tau_{0.5}-$ time of partial conversion of carbon.

In order to determine the reactivity of the coals, the reaction rate constant $k$ was also calculated for carbon conversion. The rate constant was determined according to Equation (3), the integral of which is a function described by the Equation (4):

$$
\begin{aligned}
& \frac{d X}{d \tau}=k_{c}(1-X) \\
& \tau k=\ln \left(\frac{1}{1-X}\right)
\end{aligned}
$$

$\stackrel{\leftrightarrow}{\leftrightarrow} k_{c}-$ reaction rate constant of carbon conversion $\left[\mathrm{min}^{-1}\right]$,

$X$ - carbon conversion degree after time $\tau[-]$,

$\tau \quad-$ time of gasification [min].

Assuming that the gasification reaction is of the first order, on the basis of the Equation (4) a linear graph was developed, for which the slope corresponds to the reaction rate constant $k_{c}$

The evaluation of reactivity was also carried out on the basis of the formation kinetics of major gaseous products of the gasification process, i.e. carbon mono- and dioxide, methane and hydrogen as well as by determining the reaction rate constants of their formation. The reaction rate constants of formation of gaseous products, assuming that we are dealing with the first order reaction, can be determined similarly to the way it was done for the reaction rate constant of carbon conversion using the Formula (4). However, this requires a certain modification; namely, it has to assume the form of the Equation (5): 


$$
\ln \frac{V_{\infty}}{V_{\infty}-V}=k \cdot \tau
$$

$\stackrel{4}{\rightarrow} V_{\infty}-$ maximal volume of particular gas component $\left[\mathrm{cm}^{3}\right]$,

$V-$ volume of $i$-th component after time $t\left[\mathrm{~cm}^{3}\right]$.

\section{Results and discussion}

\subsection{Reactivity of coals}

Changes in the carbon conversion degree $\mathrm{X}$ in the function of time for the examined coals are presented in Fig. 2 (in the legend, the coals have been arranged in the order of decreasing reactivity). All the curves are of a similar nature. In the first minutes, a rapid growth of the conversion degree is observed, which is connected with the course of the pyrolysis process. Next, particular curves diverge, which shows a different course of the proper, much slower, pyrolysis process. The last, horizontal part of the conversion curves is identified with the subsiding of the gasification reaction. The steepness of the conversion curves should be attributed to highly reactive coals, and a more level course to coals of lower reactivity. The reactivity of particular coals can be assessed on the basis of the shape analysis of the conversion curves. The highest reactivity is displayed by brown coals (Sieniawa, Turów, Bełchatów) and young hard coals (Piast, Janina). The remaining hard coals (Bogdanka, Wieczorek, Sobieski) should be regarded as less reactive.

The reactivity of coals is reflected in the obtained maximal values of carbon conversion degree (Table 2). The conversion degrees for the examined brown coals and hard coals ranged from 92.7 to $95.4 \%$ and from 68.4 to $84.5 \%$, respectively. A larger amount of unreacted char should be anticipated for coals with a lower conversion degree, which, in order to increase the efficiency of the process, will have to be released from gas and turned back to the gasifier. This solution is commonly applied in fluidized bed reactors (Ariyapadi et al. 2008; GTI 2016).

Table 2. Maximal value of carbon conversion degree for examined brown and hard coals

Tabela 2. Maksymalne stopnie konwersji pierwiastka $\mathrm{C}$ badanych węgli

\begin{tabular}{|c|c|c|c|c|c|c|c|c|}
\hline Coal & Sieniawa & Turów & Bełchatów & Piast & Janina & Bogdanka & Wieczorek & Sobieski \\
\hline $\begin{array}{c}\text { Conversion } \\
\text { degree }[\%]\end{array}$ & 98.8 & 95.4 & 92.8 & 84.4 & 79.5 & 73.2 & 68.5 & 68.4 \\
\hline
\end{tabular}




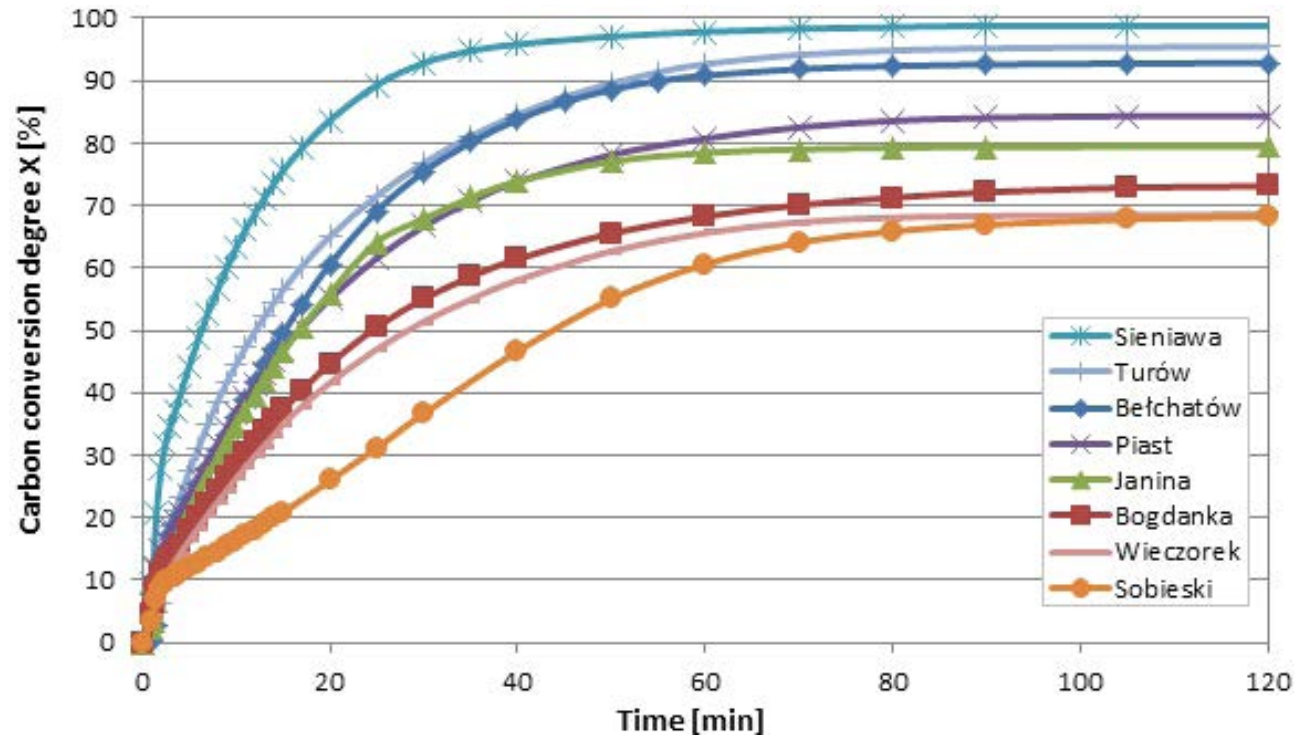

Fig. 2. Carbon conversion degree for examined brown and hard coals (in the legend coals are arranged in order of decreasing reactivity)

Rys. 2. Stopień konwersji pierwiastka C dla badanych węgli (w legendzie węgle uszeregowano w kolejności malejącej reaktywności)

Time of partial conversion $\tau_{0.5}$ for the examined coals is presented in Fig. 3 (brown coals are marked with blue color and hard coals with red). Similarly to the previously obtained results, brown coals, particularly Sieniawa, turned out to be the most reactive, though they are characterized by diverse values of the time of partial conversion $\tau_{0.5}$. There are highly

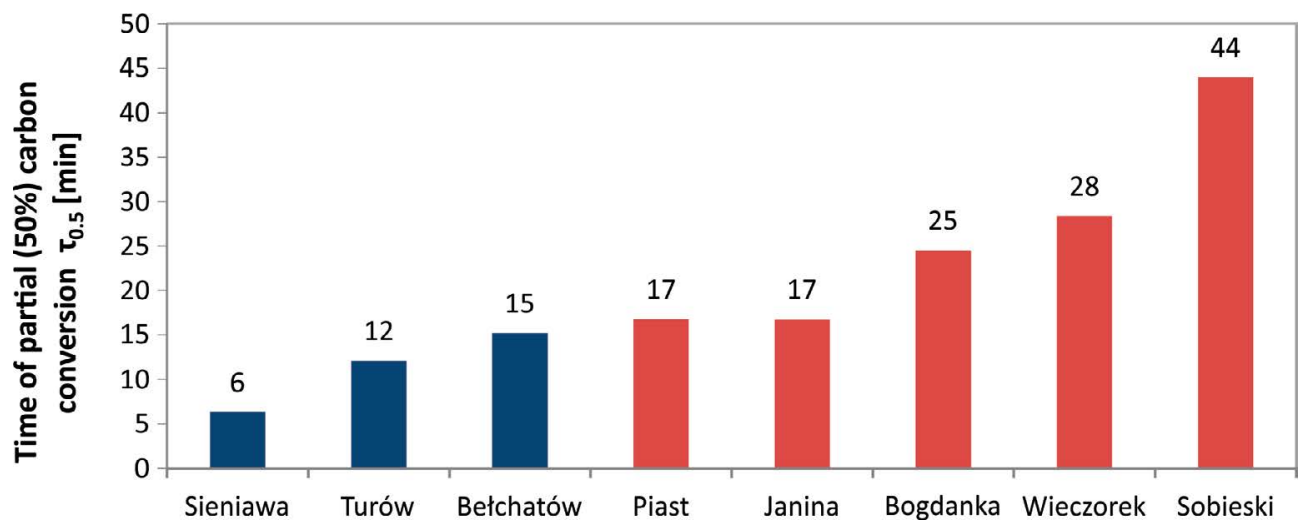

Fig. 3. Time of partial ( $50 \%$ ) carbon conversion $\tau_{0.5}$ for examined brown and hard coals (blue color - brown coals; red color - hard coals)

Rys. 3. Czas połowicznej konwersji $\tau_{0,5}$ dla przebadanych węgli (kolor niebieski - węgle brunatne; kolor czerwony - węgle kamienne) 
reactive coals (Piast and Janina) among hard coals, with the value of the $\tau_{0.5}$ index close to that of the Bełchatów brown coal, coals of medium reactivity (Bogdanka and Wieczorek) and a coal of low reactivity (Sobieski).

The $R_{0.5}$ reactivity indices determined for the examined coals are shown in Fig. 4 (brown coals are marked with blue color and hard coals with red). Similar relationships were obtained for the $R_{0.5}$ index, as in the case of the time of partial conversion $\tau_{0.5}$.

A list of the obtained results of the calculations of the reaction rate constant of carbon conversion is presented in Fig. 5. A significant conformity can be observed of the obtained

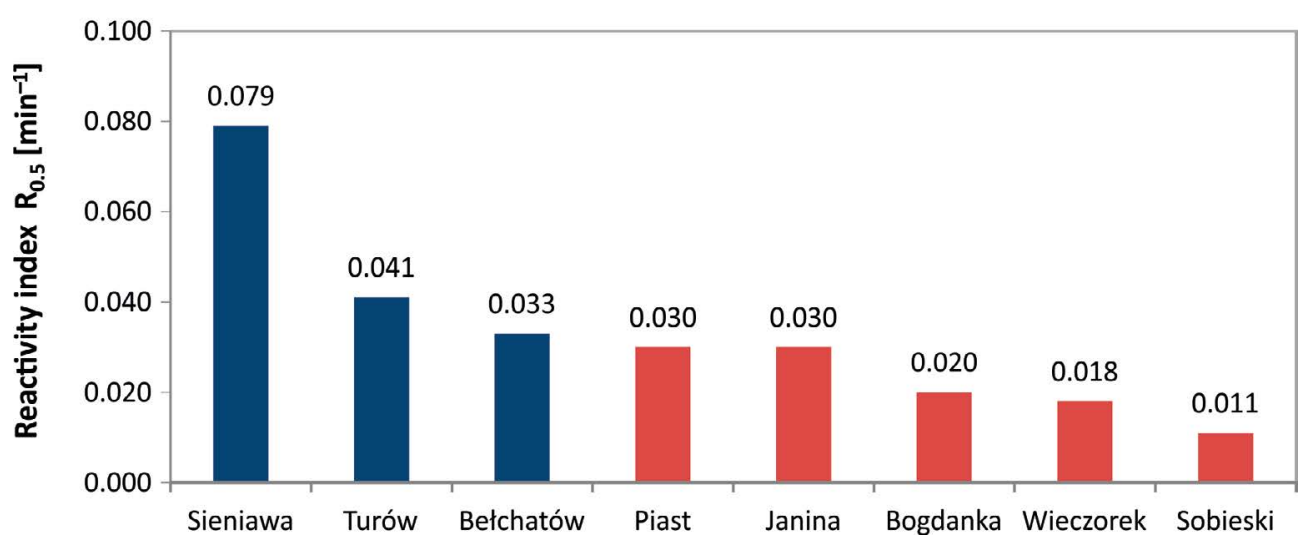

Fig. 4. Reactivity index $R_{0.5}$ for examined brown and hard coals (blue color - brown; red color - hard coals)

Rys. 4. Indeks reakcyjności $R_{0,5}$ dla przebadanych węgli (kolor niebieski - węgle brunatne; kolor czerwony - węgle kamienne)

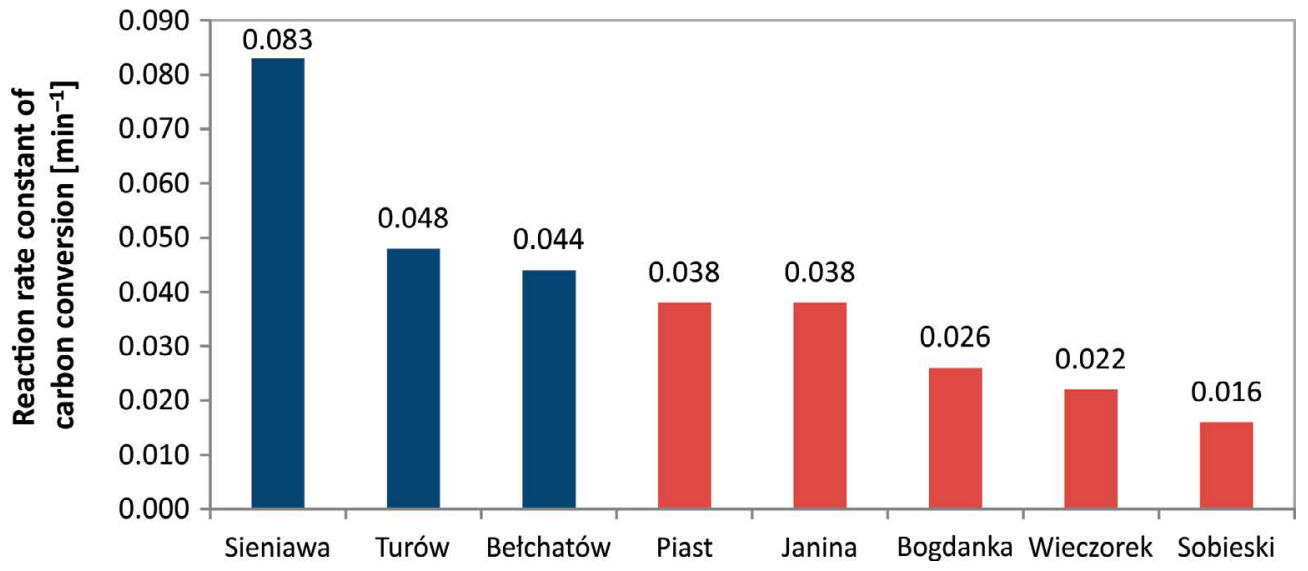

Fig. 5. Reaction rate constant of carbon conversion for examined brown and hard coals (blue color - brown coals; red color - hard coals)

Rys. 5. Stała szybkości konwersji pierwiastka C dla przebadanych węgli (kolor niebieski - węgle brunatne; kolor czerwony - węgle kamienne) 


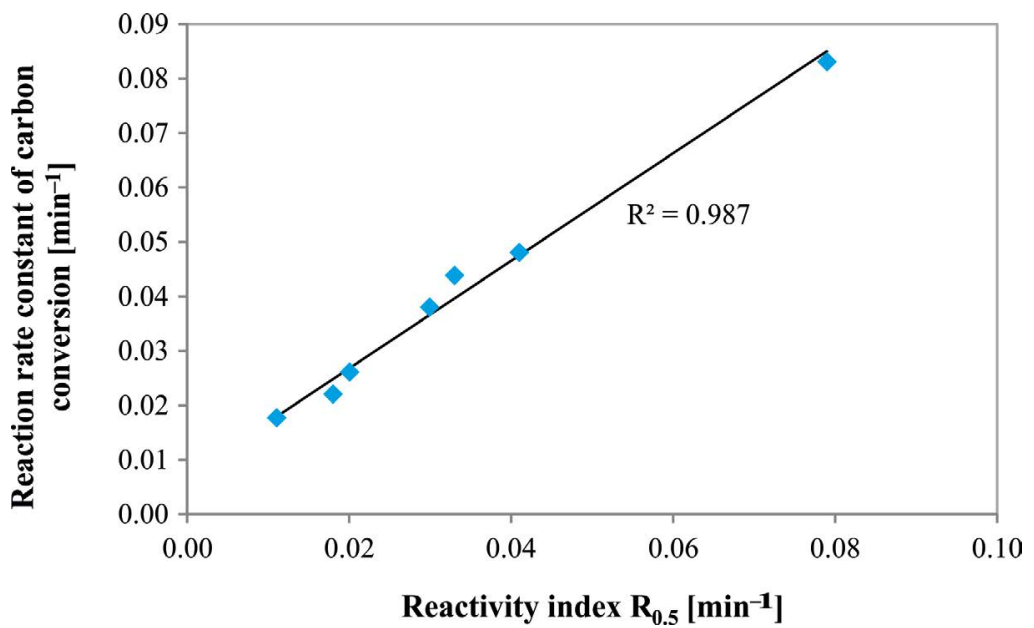

Fig. 6. Comparison of reactivity index $R_{0.5}$ and reaction rate constant of carbon conversion

Rys. 6. Porównanie indeksu reaktywności $R_{0,5}$ ze stałą szybkości konwersji pierwiastka C

reaction rate constants with the reactivity index $R_{0.5}$, both as regards the order of the coals arranged with respect to reactivity and as regards the numerical values. This is confirmed by obtaining a high value of the coefficient of determination $R^{2}=0.987$ for the relationship between both parameters - Fig. 6 .

\subsection{Formation rate of gaseous products}

The formation rate was calculated for carbon monoxide, dioxide, methane and hydrogen on the basis of changes in the composition of resulting gas. Changes in the rate as a function of time of the process are graphically presented in Fig. 7-10. Certain similarities can be observed for the formation curves of $\mathrm{CO}, \mathrm{CO}_{2}$ and $\mathrm{H}_{2}$. In the first minutes, a rapid growth is recorded of the formation rate of gases, for which the pyrolysis process is responsible. Next, the formation rates of gaseous products are much lower, and, at that time, the char formed in the pyrolysis process is gasified.

The curves for methane constitute an exception, and from their shape it can be concluded that methane is formed mainly during the pyrolysis process; hence, these curves are unsuitable for evaluating the reactivity of coals in the process of steam gasification. Analyzing the shape of the curves of the formation rate changes for carbon monoxide and dioxide as well as hydrogen, it can be stated that an evaluation of the reactivity of coals is possible for the curves of $\mathrm{CO}$ and $\mathrm{H}_{2}$ formation (Fig. 7 and 8). In the case of the curve of $\mathrm{CO}_{2}$ formation, the results are vague and difficult to analyze. Analyzing the curves of formation of $\mathrm{CO}$ and $\mathrm{H}_{2}$, it can be concluded that the obtained results are consistent with the results concerning 


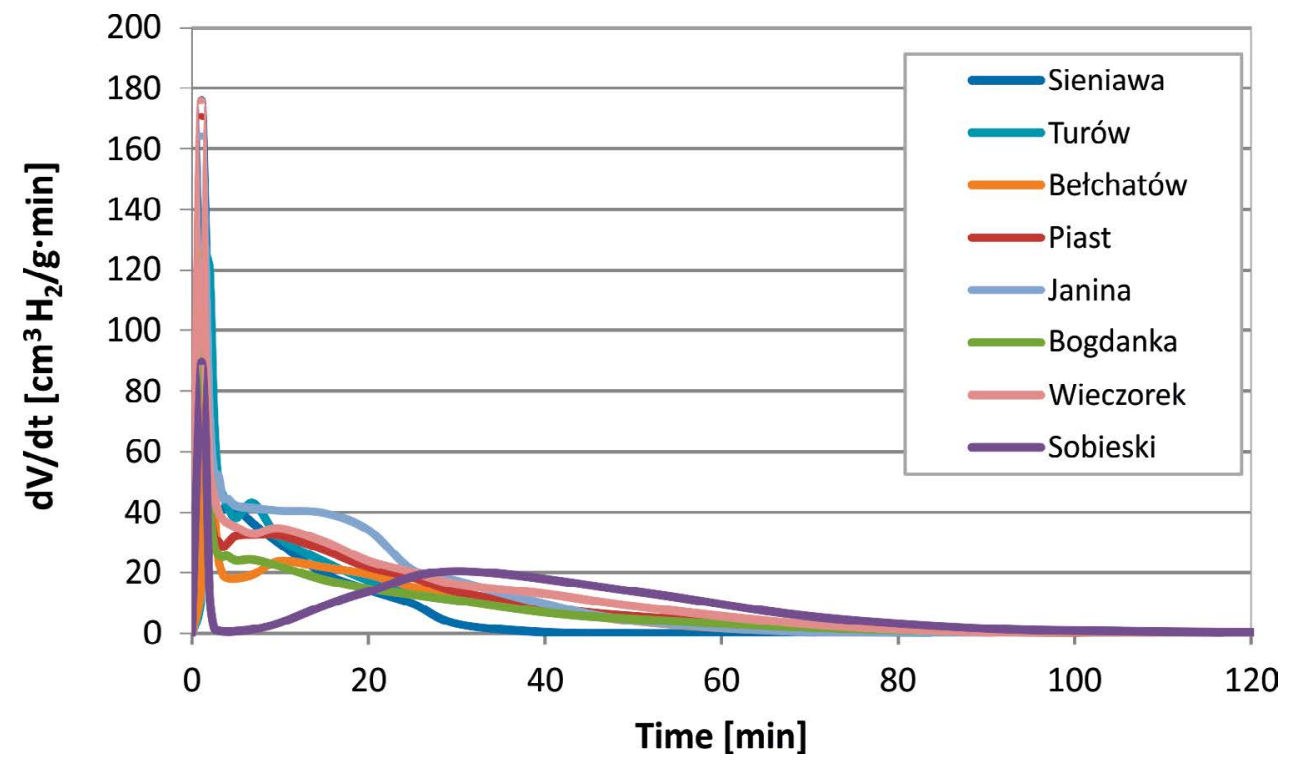

Fig. 7. Changes in $\mathrm{H}_{2}$ formation rate during the gasification of the examined coals

Rys. 7. Zmiany szybkości wydzielania wodoru w procesie zgazowania badanych węgli

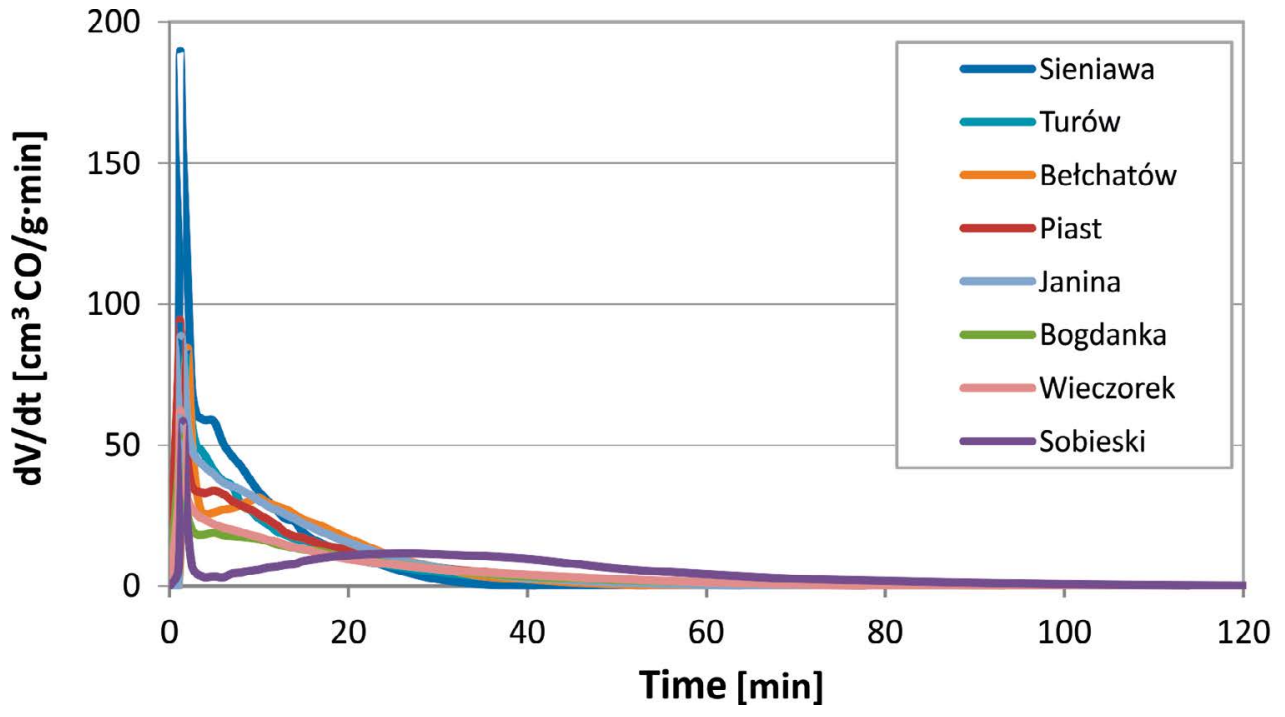

Fig. 8. Changes in $\mathrm{CO}$ formation rate during the gasification of the examined coals

Rys. 8. Zmiany szybkości wydzielania tlenku węgla w procesie zgazowania badanych węgli 


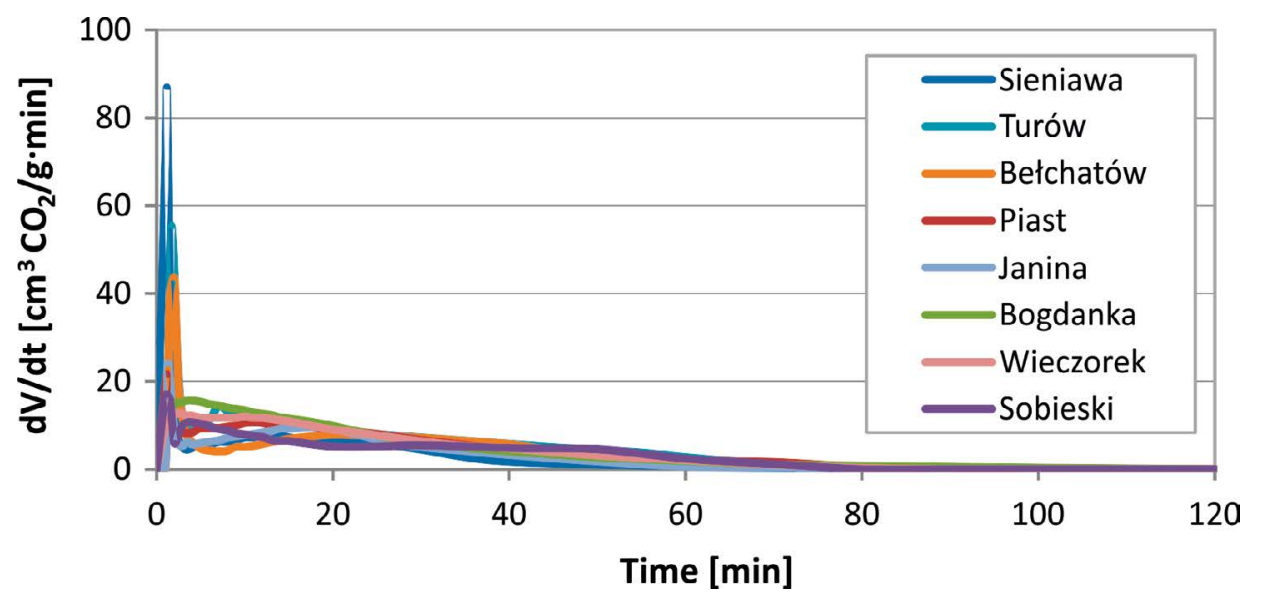

Fig. 9. Changes in $\mathrm{CO}_{2}$ formation rate during the gasification of the examined coals

Rys. 9. Zmiany szybkości wydzielania ditlenku węgla w procesie zgazowania badanych węgli

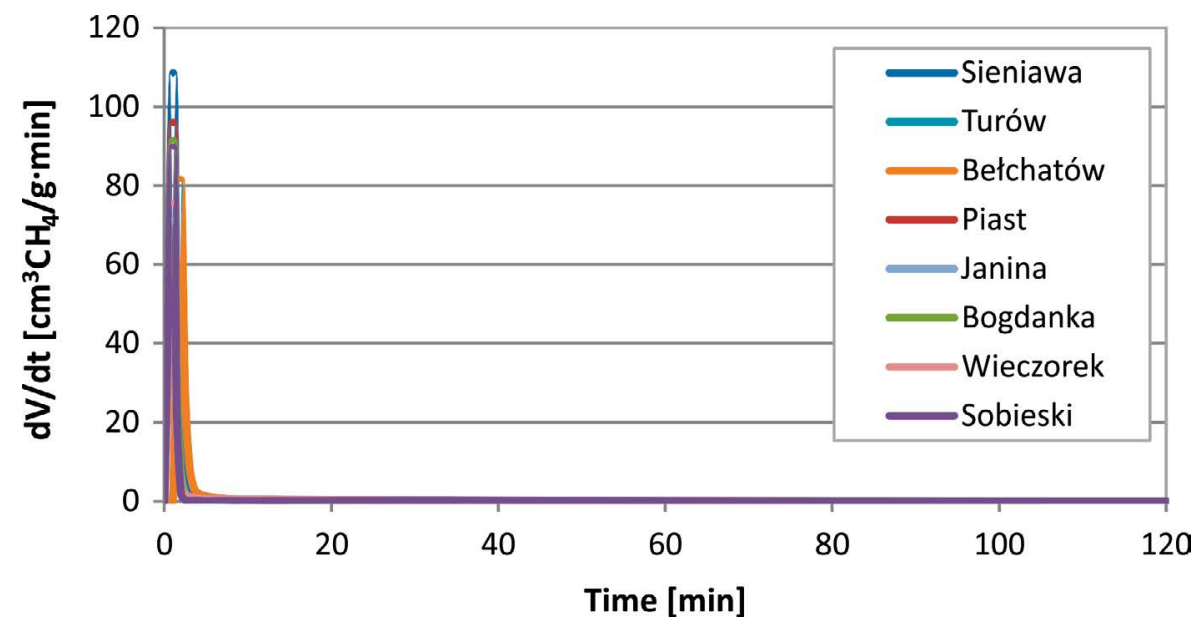

Fig. 10. Changes in $\mathrm{CH}_{4}$ formation rate during the gasification of the examined coals

Rys. 10. Zmiany szybkości wydzielania metanu w procesie zgazowania badanych węgli

the reactivity presented earlier. The process of gasification for the examined coals lasted from 40-120 minutes, which should be attributed to the different reactivity of the examined coals.

Table 3 presents the calculated values of the formation rate constants for hydrogen, carbon mono- as well as dioxide, i.e. $k_{\mathrm{H}_{2}}, k_{\mathrm{CO}}, k_{\mathrm{CO}}$. The obtained results demonstrate a similar tendency to the results obtained for the reactivity index $R_{0.5}$. The highest values of the formation rate constants of gaseous products are those for brown coals; lower values occur 
Table 3. Reaction rate constants of $\mathrm{H}_{2}, \mathrm{CO}$ and $\mathrm{CO}_{2}$ formation

Tabela 3. Stałe szybkości tworzenia się produktów gazowych

\begin{tabular}{|l|c|c|c|}
\hline Coal & $\mathrm{k}_{\mathrm{H}_{2}}\left[\mathrm{~min}^{-1}\right]$ & $\mathrm{k}_{\mathrm{CO}}\left[\mathrm{min}^{-1}\right]$ & $\mathrm{k}_{\mathrm{CO}_{2}}\left[\mathrm{~min}^{-1}\right]$ \\
\hline Sieniawa & 0.128 & 0.103 & 0.058 \\
\hline Turów & 0.061 & 0.100 & 0.048 \\
\hline Bełchatów & 0.052 & 0.103 & 0.049 \\
\hline Piast & 0.053 & 0.064 & 0.047 \\
\hline Janina & 0.075 & 0.076 & 0.058 \\
\hline Bogdanka & 0.051 & 0.050 & 0.045 \\
\hline Wieczorek & 0.058 & 0.058 & 0.053 \\
\hline Sobieski & 0.041 & 0.037 & 0.043 \\
\hline
\end{tabular}

for highly reactive hard coals (Janina and Piast), still lower ones for hard coals of medium reactivity (Bogdanka and Wieczorek), and the lowest values for the hard coal of low reactivity (Sobieski).

\subsection{Yields and composition of gas from coal gasification}

Table 4 shows the calorific value of the obtained gaseous products and the yields of particular gaseous components obtained from $1 \mathrm{~g}$ of coal as per the dry and ash free basis. The

Table 4. Yields of $\mathrm{CO}, \mathrm{CO}_{2}, \mathrm{CH}_{4}$ and $\mathrm{H}_{2}$ [ $\mathrm{cm}^{3}$ per $1 \mathrm{~g}$ of dry and ash free coal] and calorific value of the gas obtained during the gasification of the examined coals

Tabela 4. Wydajność $\mathrm{CO}, \mathrm{CO}_{2}, \mathrm{CH}_{4} \mathrm{i} \mathrm{H}_{2}$ [ $\mathrm{cm}^{3}$ na $1 \mathrm{~g}$ węgla w stanie suchym i bezpopiołowym] oraz kaloryczność gazów uzyskanych z procesu zgazowania badanych węgli

\begin{tabular}{|l|r|r|r|r|r|r|c|}
\hline \multirow{2}{*}{ Coal } & \multicolumn{5}{|c|}{ Yields of particular gaseous $\left[\mathrm{cm}^{3}\right]$} & \multicolumn{2}{c|}{ Calorific value $\left[\mathrm{MJ} / \mathrm{m}^{3}\right]$} \\
\cline { 2 - 8 } & $\mathrm{CO}$ & $\mathrm{CO}_{2}$ & $\mathrm{CH}_{4}$ & \multicolumn{1}{c|}{$\mathrm{H}_{2}$} & total & LHV & HHV \\
\hline Sieniawa & 891 & 326 & 120 & 850 & 2187 & 11.3 & 12.3 \\
\hline Turów & 643 & 521 & 96 & 1068 & 2328 & 9.9 & 11.0 \\
\hline Bełchatów & 706 & 394 & 70 & 859 & 2029 & 10.2 & 11.2 \\
\hline Piast & 749 & 429 & 101 & 1208 & 2487 & 10.5 & 11.6 \\
\hline Janina & 791 & 314 & 80 & 1434 & 2619 & 10.8 & 12.0 \\
\hline Bogdanka & 544 & 479 & 99 & 906 & 2027 & 10.0 & 11.0 \\
\hline Wieczorek & 566 & 445 & 83 & 1399 & 2493 & 10.1 & 11.4 \\
\hline Sobieski & 611 & 373 & 89 & 1024 & 2097 & 10.5 & 11.6 \\
\hline
\end{tabular}


composition of the resulting gas is compared in Fig. 11. It can be stated that the resulting gas had a similar composition. For each case, the highest share is that of hydrogen, then carbon monoxide and carbon dioxide, while the lowest share was obtained for methane. The combined content of carbon monoxide and hydrogen ranged from 72 to $85 \%$, which is a typical value for the steam gasification of coal (Zheng and Furnisky 2005). The obtained ratio of $\mathrm{H}_{2}$ to $\mathrm{CO}$ for particular coals ranged from 0.95 to 2.47 . The calorific values of the obtained gases are also typical for the process of coal gasification with steam.

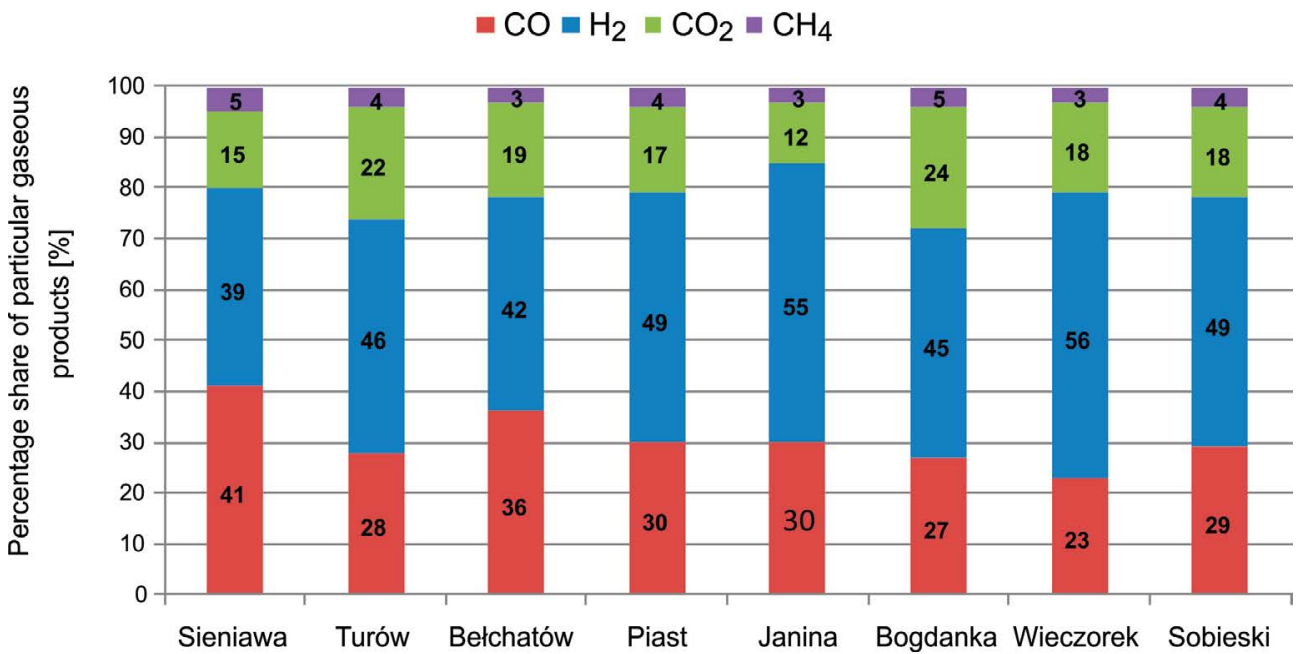

Fig. 11. Composition of gas resulting from the gasification of the examined coals

Rys. 11. Skład gazów uzyskanych w procesie zgazowania badanych węgli

It should be remembered that the composition of gas obtained in gasifiers is influenced not only by the applied raw material but also by process parameters and technological solutions of the gasifiers (Czerski et al. 2014) as well as by the processes of gas cleaning and conditioning (Chmielniak et al. 2014; Zheng andFurnisky 2005). In the case of using gas for chemical syntheses in order to obtain the optimal $\mathrm{H}_{2}: \mathrm{CO}$ ratio, the process of carbon monoxide conversion with steam (WGS - water-gas shift reaction) is commonly used.

\subsection{Coal ash fusibility}

The melting behavior of ash is a very important process parameter for all types of reactors, as it determines the boundary temperature for conducting the process. In the case of dry bottom reactors, the process of gasification should be conducted at a temperature lower 
than the temperature of ash melting, and in the case reactors with wet bottom reactors, at a higher temperature.

Table 5 shows the result of coal ash fusibility for the examined coals. For all the analyzed cases, the temperature of ash melting (hemispherical temperature) exceeds $1300^{\circ} \mathrm{C}$. In the case of fixed bed reactors, for the dry bottom version, the temperature of ash melting should be higher than $1200^{\circ} \mathrm{C}$, and for the wet bottom version it should be lower than $1300^{\circ} \mathrm{C}$ (Chmielniak 2008). The analyzed coals can then be used in fixed bed dry bottom reactors.

Table 5. Ash fusibility results for examined coals

Tabela 5. Temperatury topliwości popiołów dla wybranych węgli

\begin{tabular}{|l|c|c|c|c|}
\hline \multirow{2}{*}{ Coal } & \multicolumn{4}{|c|}{ Temperature of $\left[{ }^{\circ} \mathrm{C}\right]$} \\
\cline { 2 - 5 } & initial deformation & spherelsoftening & hemispherical & fluid \\
\hline Sieniawa & 1200 & 1200 & 1200 & 1240 \\
\hline Bełchatów & 920 & 1370 & 1380 & 1420 \\
\hline Turów & 960 & 1250 & 1350 & 1410 \\
\hline Janina & 880 & 1270 & 1350 & 1400 \\
\hline Piast & 910 & 1310 & 1330 & 1430 \\
\hline Bogdanka & 930 & 1540 & 1550 & 1560 \\
\hline Wieczorek & 900 & 1240 & 1310 & 1360 \\
\hline Sobieski & 950 & 1390 & 1410 & 1420 \\
\hline
\end{tabular}

As regards the fluidized bed reactors, the required melting temperature of ash should be higher than $1100^{\circ} \mathrm{C}$, and all the analyzed coals satisfy this condition. For the entrained bed reactors (Collot 2006), the melting temperature of ash should be lower than the operating temperature of the gasifier $\left(1400-1600^{\circ} \mathrm{C}\right)$; hence, all the analyzed coals can be applied in them, except for the Bogdanka coal. In the case of this coal, it will be necessary to use additives reducing the melting temperature of coal ash.

It should be stressed that for the entrained bed reactors, apart from the melting temperature of ash, the viscosity of liquid ash, enabling its flow down the walls of the reactor to the water bath, is also important. In order to ensure the smooth operation of the entrained bed reactor, the viscosity of molten ash should be equal to 5-25 $\mathrm{Pa} \cdot \mathrm{s}$ within the temperature range of $1400-1500^{\circ} \mathrm{C}$ (Wang and Massoudi 2013). 


\subsection{Content of impurities}

Figure 12 represents the content of selected impurities in coal, i.e. sulfur, chlorine and mercury (as per dry state). In the gasification process, environmentally harmful and highly corrosive compounds of $\mathrm{H}_{2} \mathrm{~S}, \mathrm{COS}$ or $\mathrm{HCl}$ are formed from sulfur and chlorine. Additionally, $\mathrm{HCl}$ in a reaction with compounds of metals contained in fly ash can form undesirable deposits.

Moreover, the content of sulfuric compounds in gas has a negative impact on the catalytic processes of syngas conversion. Therefore, before the further utilization of gas, sulfuric compounds have to be removed from it. The examined coals were featured by a diverse sulfur content from $0.36 \%$ for the Wieczorek coal to $2.35 \%$ for the Sieniawa coal, and of chlorine, from $0.007 \%$ for the Bełchatów coal to $0.353 \%$ for the Janina coal. It can be observed that hard coals were characterized by a higher content of chlorine than brown coals.

Mercury contained in coal does not have a negative impact on the operation of the plant, but it constitutes a source of mercury emission to the environment. Mercury emitted to the environment follows natural circulation there and enters the human body, where it undergoes bioaccumulation, which can result in undesirable effects. Therefore, nowadays, a reduction of mercury emission from the processes of coal combustion is becoming increasingly important. This especially applies to coal-fired power plants (Burmistrz et al 2014), which are the major consumer of coal, but also gasification plants (Chmielniak et al. 2014).

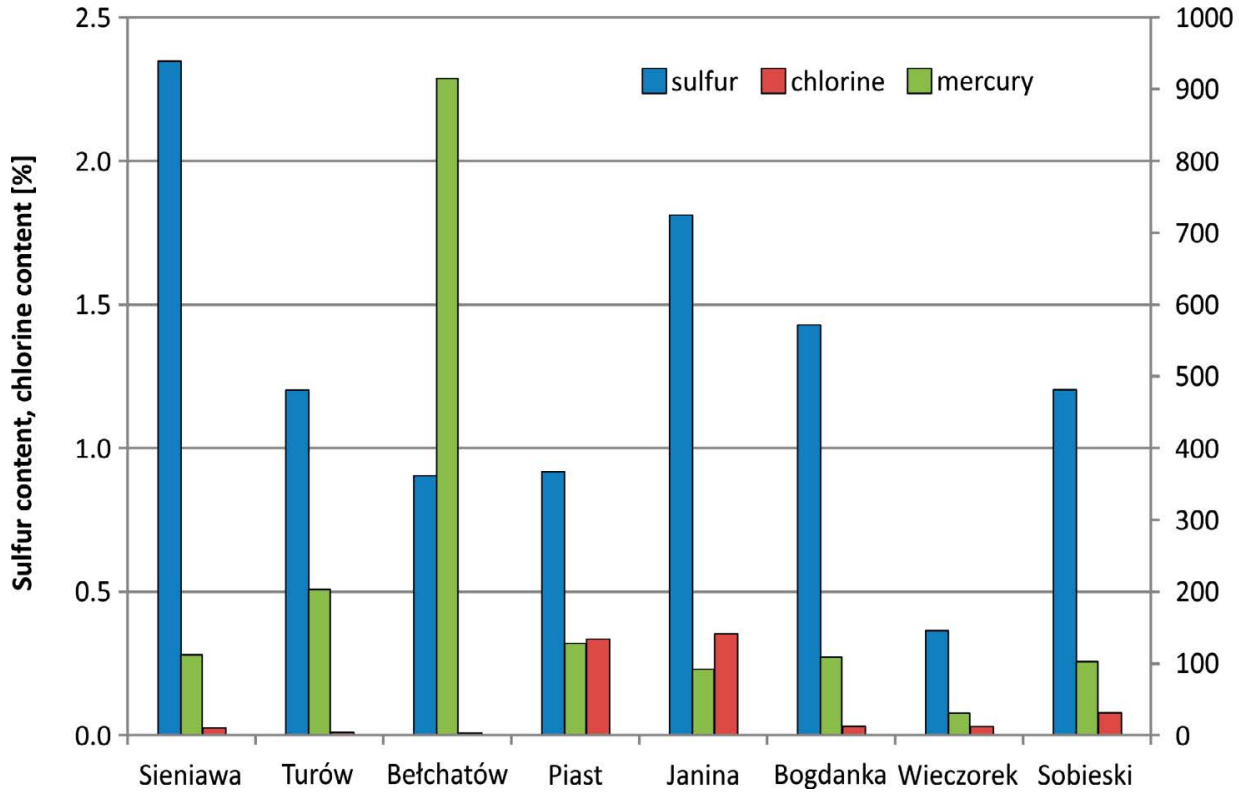

Fig. 12. Sulphur, chlorine and mercury content in examined coals (dry basis)

Rys. 12. Zawartość siarki, chloru i rtęci w badanych węglach (stan suchy) 
A reduction of mercury emission from the gasification plants can be achieved in a number of ways: through mercury capture from gas (Burmistrz et al 2014; Chmielniak et al. 2014) or through a decrease of its content in coal before the coal gasification process (Chmielniak 2011; Dziok et al. 2014, 2015). For brown and hard coals, a reduction of mercury content in coal can be attained in the processes of its thermal pre-treatment and, additionally, in the case of hard coals, by applying methods of their cleaning. The content of mercury in the analyzed coals ranged from $31 \mathrm{ppb}$ for the Wieczorek coal to $915 \mathrm{ppb}$ for the Bełchatów coal. It can be observed that brown coals are featured by higher contents of mercury when compared to hard coals.

\section{Conclusions}

The presented examinations allowed for an evaluation of suitability of the examined coals for gasification. One of the most important criteria for evaluating the suitability of the examined coals for gasification is their reactivity. This can be determined with the use of the equipment and methodology presented in the paper. The reactivity of coals with respect to steam can successfully be determined in various ways, i.e. through a comparison of the shape of carbon conversion curves, determination of time of the partial conversion of carbon $\tau_{0.5}$, and the reactivity index $R_{0.5}$ or the reaction rate constant of carbon conversion as well as through drawing conclusions on the basis of the formation kinetics of gaseous products and the calculation of the reaction rate constants of their formation. The obtained results for various methods of reactivity evaluation are consistent with one another.

The examined coals can be arranged in respect of their reactivity. The highest reactivity was demonstrated by brown coals (Sieniawa $>$ Turów $>$ Bełchatów). Highly reactive coals can be found (Piast $\geq$ Janina) among hard coals as well as those of medium reactivity (Bogdanka $>$ Wieczorek) and a coal of low reactivity (Sobieski). The reactivity of coals is an especially important parameter in the case of fluidized bed gasifiers, which operate at a relatively low temperatures. The reactivity of coals influenced the maximal values of the carbon conversion degree which ranged from 92.7 to $95.4 \%$ for brown coals and from 68.4 to $84.5 \%$ for hard coals.

The gases formed in the process of gasification had similar compositions, and the highest share was that of hydrogen, then carbon monoxide and carbon dioxide, while the lowest share was obtained for methane. The shape of the curves of formation of particular components of gas was also similar for all the examined coals. The reactivity of the examined coal can also be indirectly evaluated on the basis of the shape of the curves and the duration of the process.

An analysis of the coal ash fusibility showed that all the examined coals can be used in fixed bed dry bottom reactors as well as in fluidized bed reactors. In entrained bed reactors a direct use of all the coals is possible, except for the Bogdanka coal. In the case of this coal, using additives reducing the melting temperature of coal ash will be necessary. 
The examined coals were featured by a diverse content of impurities: sulfur from 0.36 to $2.35 \%$, chlorine from 0.007 to $0.353 \%$ and mercury from 31 to $915 \mathrm{ppb}$ (as per dry state).

Brown coals had a lower content of chlorine and, at the same time, a higher content of mercury when compared to hard coals.

This paper was prepared as a part of the statutory activity of the Faculty of Energy and Fuels at the AGH University of Science and Technology, No. 11.11.210.213.

\section{REFERENCES}

Ariyapadi et al. 2008 - Ariyapadi, S., Shires, P., Bhargava, M. and Ebbern, D. 2008. KBR's Transport Gasifier $\left(\mathrm{TRIG}^{\mathrm{TM}}\right)$ - an advanced gasification technology for SNG production from low-rank coals. $25^{\text {th }}$ Annual Internationa Pittsburgh Coal Conference. Pittsburgh PA, 29 September-2 October 2008.

Burmistrz et al. 2014 - Burmistrz, P., Czepirski, L., Kogut, K. and Strugała, A. 2014. Removing mercury from flue gases. A demo plant based on injecting dusty sorbents. Przem. Chem. 93(12), pp. 2014-2019 (in Polish).

Chmielniak, T. 2008. Coal gasification, State of technological development [In:] Borowiecki T., Kijeński J., Machnikowski J. and Ściążko M. ed. Clean Energy, chemical products and fuels from coal - an evaluation of Development Potential. Zabrze: IChPW, pp. 94-111 (in Polish).

Chmielniak, T. 2011. Reduction of mercury emissions to the atmosphere from coal combustion processes using low temperature pyrolysis - a concept of process implementation on a commercial scale. Rynek Energii 93(2), pp. 176-181.

Chmielniak et al. 2014 - Chmielniak, T., Bigda, J., Czardybon, A., Popowicz, J. and Tomaszewicz, G. 2014. Technologies for syngas cleaning produced from the coal gasification. Przem. Chem. 93(2), pp. 232-242 (in Polish).

Collot A.G. 2006. Matching gasification technologies to coal properties. International Journal of Coal Geology 65, pp. 191-212.

Coetzee et al. 2013 - Coetzee, S., Neomagus, H.W.J.P., Bunt, J.R. and Everson, R.C. 2013. Improved reactivity of large coal particles by $\mathrm{K}_{2} \mathrm{CO}_{3}$ addition during steam gasification. Fuel Processing Technology 114, pp. 75-80.

Czerski et al. 2014 - Czerski, G., Dziok, T., Strugała, A. and Porada, S. 2014. Suitability of coal gasification technologies for the chemical industry. Przem. Chem. 93(8), pp. 1393-1400 (in Polish).

Darby, A. 2014. Compact gasification integration studies. Gasification Technology Conference, Washington DC, 27 October 2014

Dreszer, K. and Więcław Solny, L. 2007. Coal gasification and liquid fuels synthesis. Gospodarka Surowcami Mineralnymi - Mineral Resources Management 23(3), pp. 93-104 (in Polish).

Dziok et al. 2014 - Dziok, T., Strugała, A., Rozwadowski, A. and Okońska, A. 2014. Effect of selected parameters of thermal pretreatment of bituminous coal on the mercury removal efficiency. Przem. Chem. 93(12), pp. 2034-2037 (in Polish).

Dziok et al. 2015 - Dziok, T., Strugała, A., Rozwadowski, A. and Macherzyński, M. 2015. Studies of the correlation between mercury content and the content of various forms of sulfur in Polish hard coals. Fuel 159, pp. 206-213.

Everson et al. 2006 -Everson, R.C., Neomagus, H.W.J.P., Kasaini, H. and Njapha, D. 2006. Reaction kinetics of pulverized coal-chars derived from inertinite-rich coal discards: Gasification with carbon dioxide and steam. Fuel 85, pp. 1076-1082.

GTI: The GTI Gasification Proccess. [Online] Available at: http://www.netl.doe.gov/File\%20Library/research/coal/ energy\%20systems/gasification/gasifipedia/GTIGasificationProcess9_18_07.pdf [Accessed: 5.02. 2016].

Higman, C. 2014. State of the gasification industry - Worldwide Gasification Database 2014 Update. Gasification Technology Conference, Washington DC, 29 October 2014. 
Howard, W. 2013. Westinghouse plasma gasification - industrial scale syngas production from waste products. $G a-$ sification Technologies Conference, Colorado Springs CO, 13-16 October 2013.

$\mathrm{Li}, \mathrm{C}$. and Li, C.-Z. 2006. Volatilisation and catalytic effects of alkali and alkaline earth metallic species during the pyrolysis and gasification of Victorian brown coal. Part VIII. Catalysis and changes in char structure during gasification in steam. Fuel 85, pp. 1518-1525.

Matsuoka et al. 2009 - Matsuoka, K., Kajiwara, D., Kuramoto, K., Sharma, A. and Suzuki, Y. 2009. Factors affecting steam gasification rate of low rank coal char in a pressurized fluidized bed. Fuel Processing Technology 90, pp. 895-900.

Mazurkiewicz et al. 2012 - Tkaczewska, E., Pomykła, R. and Uliasz-Bocheńczyk, A. 2013. Preliminary determination of the suitability of slags resulting from coal gasification as a pozzolanic raw material. Gospodarka Surowcami Mineralnymi-Mineral Resources Management 28(4), pp. 5-14.

Mazurkiewicz et al. 2013 - Mazurkiewicz, M., Malta, G. and Uliasz-Bocheńczyk, A. 2013. Characteristics of selected wastes from carbon gasification. Gospodarka Surowcami Mineralnymi-Mineral Resources Management 29(4), pp. 119-128.

Molina, A. and Mandragon, F. 1998. Reactivity of coal gasification with steam and $\mathrm{CO}_{2}$. Fuel 77, pp. 1831-1839.

Murakami et al. 2015 - Murakami, K., Sato, M., Tsubouchi, N., Ohtsuka, Y. and Sugawara, K. 2015. Steam gasification of Indonesian subbituminous coal with calcium carbonate as a catalyst raw material. Fuel Processing Technology 129, pp. 91-97.

Peng et al. 1995 -Peng, F.F., Lee, I.C. and Yang, R.Y.K. 1995. Reactivities of in situ and ex situ coal chars during gasification in steam at $1000-1400^{\circ}$ C. Fuel Processing Technology 41, pp. 233-251.

Porada, S. and Rozwadowski, A. 2014. Kinetic study of steam gasification of bituminous coal at elevated pressures Przem. Chem. 93(12), pp. 2059-2063 (in Polish).

Porada et al. 2014a - Porada, S., Czerski, G., Dziok, T., Grzywacz, P. and Makowska, D. 2014. Comparison of steam gasification kinetics of coal and its char. Przem. Chem. 93(12), pp. 384-387 (in Polish).

Porada et al. 2014 b. - Porada, S., Grzywacz, P., Czerski, G., Kogut, K. and Makowska, D. 2014. Assessment of Polish coals suitability for gasification process. Polityka energetyczna - Energy Policy Journal 17(4), pp. 89-102.

Porada et al. 2015 - Porada, S., Czerski, G., Dziok, T., Grzywacz, P. and Makowska, D. 2015. Kinetics of steam gasification of bituminous colas in terms of their use for underground coal gasification. Fuel Processing Technology 130 , pp. 282-291.

Sharma et al. 2008 - Sharma, A., Takanohashi, T. and Saito, I. 2008. Effect of catalyst addition on gasification reactivity of HyperCoal and coal with steam at $775-700^{\circ}$ C. Fuel 87 , pp. 2686-2690.

Smoliński, A. 2011. Coal char reactivity as a fuel selection criterion for coal-based hydrogen-rich gas production in the process of steam gasification. Energy Conversion and Management 52, pp. 37-45.

Strugała, A. and Czerski, G. 2012. Studies on coal gasification in Poland. Przem Chem. 91(11), pp. 2181-2185 (in Polish).

Wang et al. 2009 - Wang, J., Jiang, M., Yao, Y., Zhang, Y. and Cao, J. 2009. Steam gasification of coal char catalyzed by $\mathrm{K}_{2} \mathrm{CO}_{3}$ for enhanced production of hydrogen without formation of methane. Fuel 88, pp. 1572-1579.

Wang et al. 2010 - Wang, J., Yao, Y., Cao, J. and Jiang, M. 2010. Enhanced catalysis of $\mathrm{K}_{2} \mathrm{CO}_{3}$ for steam gasification of coal char by using $\mathrm{Ca}(\mathrm{OH})_{2}$ in char preparation. Fuel $89(2)$, pp. 310-317.

Wang, P. and Massoudi, M. 2013. Slag behavior in gasifiers. Part I: Influence of coal properties and gasification conditions. Energies 6, pp. 784-806.

Wu et al. 2003 - Wu, Z., Sugimoto, Y., Harada, M. nad Akimoto, A. 2003. Influence of coal rank and mineral matter on char gasification. $20^{\text {th }}$ Annual International Pittsburgh Coal Conference. Pittsburgh, 15-19 September 2003.

Yasushi et al. 2006 -Yasushi, S., Ishikawa, K., Kikuchi, E., Matsukata, M. and Akimoto, A. 2006. Reactivity and structural change of coal char Turing steam gasification. Fuel 85, pp. 122-126.

Ye et al. 1998 - Ye, D.P., Agnew, J.B. and Zhang, D.K. 1998. Gasification of a South Australian low-rank coal with carbon dioxide and steam: kinetics and studies. Fuel 77, pp. 1209-1219.

Zhang et al. 2013 - Zhang, L.X., Kudo, S., Tsubouchi, N. and Hayashi, J.I. 2013. Catalytic effects of Na and Ca from inexpensive materials on in-situ steam gasification of char from rapid pyrolysis of low rank coal in a drop-tube reactor. Fuel Processing Technology 113, pp. 1-7. 
Zheng L. and Furinsky E. 2005. Comparison of Shell, Texaco, BGL and KRW gasifiers as part of IGCC plant computer simulation. Energy Conversion and Management 46, pp. 1767-1779.

\title{
BADANIA POLSKICH WĘLLI BRUNATNYCH I KAMIENNYCH W KONTEKŚCIE ICH ZASTOSOWANIA W PROCESIE ZGAZOWANIA PARA WODNA
}

\author{
Słowa kluczowe
}

węgiel kamienny, węgiel brunatny, zgazowanie parą wodną, reaktywność

\section{Streszczenie}

W pracy, w celu określenia przydatności polskich węgli dla potrzeb procesu zgazowania parą wodną, przebadano pięć polskich węgli kamiennych i trzy brunatne stosowane do wytwarzania energii elektrycznej i ciepła. Badania procesu zgazowania parą wodną przeprowadzono na instalacji badawczej, która umożliwia pomiary w szerokim zakresie ciśnień metodą termowolumetryczną. Oceny reaktywności badanych węgli przeprowadzono, opierając się na przebiegu krzywych kinetycznych wydzielania się głównych produktów zgazowania oraz porównując krzywe stopnia konwersji pierwiastka $\mathrm{C}$ w badanych surowcach. Dla oceny reaktywności badanych węgli wykorzystano: porównanie przebiegu krzywych stopnia konwersji pierwiastka $\mathrm{C}$ oraz maksymalnego stopienia konwersji, czas połowicznej konwersji $\tau_{0,5}$, indeks reakcyjności $R_{0,5}$ oraz stałą szybkości konwersji pierwiastka C. Wyznaczono również uzyski i skład wytwarzanego gazu, a także obliczono stałe szybkości tworzenia się poszczególnych produktów gazowych zgazowania. Dodatkowo dla analizowanych węgli podano temperatury topliwości popiołu oraz zawartość wybranych zanieczyszczeń: siarki, chloru i rtęci.

\section{EXAMINATIONS OF POLISH BROWN AND HARD COALS IN TERMS OF THEIR USE IN THE STEAM GASIFICATION PROCESS}

\author{
Keywords
}

brown coal, hard coal, steam gasification, reactivity

\section{Abstract}

In order to determine the suitability of Polish coals for steam gasification, five Polish hard coals and three brown coals, which are used for power and heat production, were examined in this work. The examinations of the process of steam gasification were conducted with the use of a laboratory plant which allows for measurements within a broad pressure range with the thermovolumetric method. Reactivity evaluations for the examined coals were conducted on the basis of an analysis of the 
shape of the kinetic curves of formation of major gasification products and a comparison of the curves of the carbon conversion degree of the examined raw materials. In order to evaluate the reactivity of the examined coals, the following factors were utilized: a comparison of the shape of the curves of the carbon conversion degree and the maximal value of the carbon conversion degree, the time of partial conversion $\tau_{0.5}$, the reactivity index $R_{0.5}$, as well as the reaction rate constant of carbon conversion. The yields, composition and calorific value of the resulting gas were determined as well as the reaction rate constants of formation of particular gaseous products of gasification. Additionally, for the examined coals, ash fusibility and the content of selected impurities, e.g. sulfur, chlorine and mercury, were given. 